\title{
The marketing of public libraries
}

\subsection{Introduction}

Marketing is much more than advertising, selling, persuasion or promotion. Marketing is a tried and true systematic approach that relies on designing the service or product in terms of the customers' needs and desires, with satisfaction as its goal.

\subsection{Marketing tools}

The marketing function is the driving force of any successful business or library and is comprised of four major tools. These include: 1) marketing research; 2) marketing segmentation; 3) the marketing mix strategy (the 4 P's - product, price, place and promotion); and 4) marketing evaluation. Library managers can use these marketing tools to identify and understand the needs of their customers and plan to effectively meet their needs.

\subsubsection{Marketing research}

Marketing research is a planning process of finding out all about the library's markets. A market or the ideal potential market is all the people who have some stated interest in a particular product or service or could be expected to do so. The internal records of the library contain valuable market information about actual customers including: circulation data which might provide the geographic residence of customers as well as age, sex and type of reading material checked out. Other use data may include number and type of reference questions, and online searches performed and the subjects of the searches. 
Market research of society as a whole, regarding potential customer demographics, trends in health, sexual mores, entertainment and sports, are all important in assessing the information, education and entertainment needs of the library's population. This information is useful if not essential for developing the library's collection of services and materials and programmes. Library managers must be cognisant of legal aspects of customer data.

- Ohio Library Council

<http://www.olc.org/marketing/index.html> offers six different modules that are entitled overview, planning, product, promotion, Internet, and Ohio.

- Webjunction <http://www.webjunction.org/marketing> is an online resource offering expertise on marketing related topics for library and information professionals.

- North Suburban Library, USA website <http://www.nsls.info/resources/marketing/> includes articles on marketing generalizable to any library. There are podcasts, sample marketing plans, and a toolkit.

- The US Public Library Geographic Database is a free Internetbased map of US public library locations and customer data. <http://geolib.org/PLGDB.cfm>

\subsubsection{Marketing segmentation}

The second step marketing tool which is necessarily based upon marketing research is segmentation. A market segment is a group of potential customers who share similar wants and needs. Market segmentation is based on the fact that markets are heterogeneous. It is imperative for library managers to define and understand various markets in order to allocate resources efficiently and to provide services effectively.

Libraries segment customer markets in a variety of ways. By materials and services, for example fiction readers, storyhour attendees, genealogy enthusiasts, online customers. Or perhaps by age groups, such as young adults, juveniles, adults, the elderly. By contrast a university typically segments by field of study, or class level - freshmen, sophomore, junior, senior, graduate student - or by faculty, staff or community member. 
The private sector learned long ago that treating all customers the same may achieve profit on some levels. But they also learned when the differences of customers within the market are ignored, the result may be that no one is really getting what they want and need from a product or service designed for a mass market.

\subsubsection{Marketing mix strategy}

Most organisations (libraries included) offer limited resources and therefore must allocate these resources accordingly. For example, the reference service must support the goals and objectives of the library. But it must also meet (or attempt to meet) the needs of every individual that accesses the website, calls in or walks in. Therefore, this third step of the marketing model which develops product, price, place and promotion [4 Ps] of materials and services and programmes based upon market research to various market segments assists the libraries in utilising these limited funds in an efficient and effective manner. While the mix is the most visible part of the marketing model, it is not exclusively the most important.

Librarians historically participate heavily in the promotion arm of the mix. Promotion is sometimes confused with public relations which is a two-way communication that depends on feedback. Promotion simply articulates what the library is doing and what it is. Little explicit regard is typically given to the rest of the mix strategy including aspects of price (sum of cost to customers); place (of delivery i.e., branches, website); and products (books, computer access, librarian assistance and other services) when considering which segments to prioritise service to.

- LibraryJournal.com contains the Bubble Room <http://www.libraryjournal.com/blog/820000682.html> providing many links to various timely marketing articles that focus on library marketing.

- KnowThis.com's free Principles of Marketing tutorial series focuses on the key concepts and functions that are common to most marketing situations no matter what an organisation's size, industry, geographic location. <http://www.knowthis.com/principles-of-marketing-tutorials/>

- American Marketing Association (AMA) <http://www.marketingpower.com> includes AMA Publications, 
articles, webcasts, podcasts, directories, and journals. It is searchable by topic, phrase, date, author, or content source. Because one of the primary goals of the AMA is to educate and train future marketers, much of this information is available for free online.

- The "M" Word - Marketing Libraries is authored by Nancy Dowd and Kathy Dempsey.

<http://themwordblog.blogspot.com/index.html.> This blog helps librarians understand how to optimally market their library, and is regularly updated with stories and information focusing on tips and tricks for marketing the unique aspects of libraries.

- "Marketing-mantra-for-librarians" is a blog authored by Dinesh Gupta, India, offering advice and tips on library marketing and user-focused services.

<http://marketing-mantra-for-librarians.blogspot.com/>

\subsubsection{Promotion plan}

To enable the library to achieve its marketing strategy, a coherent promotional plan should be developed. It could include the following elements:

- making positive use of print, electronic and communications media

- links to and from related websites and portals

- library websites, podcasts and RSS feeds

- social media such as Facebook, Twitter and YouTube

- regular publications and the preparation of resource lists and pamphlets

- displays and exhibits

- effective interior and exterior sign-posting

- book fairs

- friends of the library groups

- annual library week celebrations and other collective promotional activities

- special years of celebration and anniversaries

- fund-raising activities and campaigns

- public-speaking activities and liaison with community groups

- reading and literacy campaigns

- designing campaigns to meet the needs of people with physical and sensory disabilities

- library listings in the telephone book and other community directories

- web links to other community agencies/directories 
- special library publications, e.g., history of the library, or community

- special reports designed for the public and local government

This list is not exhaustive and other elements can be added depending on local circumstances and customer segment use of specific media.

\subsubsection{Marketing evaluation}

Marketing evaluation includes two major methods. One is assessing customer behaviour (i.e. how many signed up for virtual reference, what time of day are questions most often asked, which subject areas are most popular?) The other attempts to measure customer satisfaction (i.e. how well does the service meet customer needs, what benefits are received, and how likely are they to use the service again?) The first process also requires gathering internal customer data, while the latter activity, that of measuring customer satisfaction, can only come from data gathered by asking customers questions through personal interview, online or print survey, focus groups, and other methodologies.

- Sponsored by the Graduate School of Library and Information Science, University of Illinois at Urbana-Champaign, USA, this site offers citations to articles, books, marketing strategies, and examples of how to best communicate with diverse populations. Web resources are available directing the reader to best marketing practices of libraries. <http://clips.lis.uiuc.edu/2003_09.html>

\subsection{Marketing and communications policy}

The library should have a written communications, marketing and promotions policy to enable it to undertake planned programmes of same to the public. The policy should include considerations of any legal factors; stated responsibilities for media interaction; technology barriers or opportunities; appropriate written and oral communication methods; and overall marketing and communication strategies of the organisation which facilitate the mission.

- Libraries are accessing social media to engage customers, and necessarily developing specialized policies and procedures. Examples of these policies are cited. <http://www.schoollibraryjournal.com/article/CA6699104.html> 


\subsection{Public relations}

Public relations (PR) is the practice of managing the flow of information between a library and its community. Public relations gains the library exposure to their community and customer markets using topics of interest and news items that do not require direct payment. Effective PR includes successful relationshps with media personnel and community groups and leaders.

- CanalBib, is a Youtube selection, offering videos related to library PR and library customers.

<http://www.youtube.com/user/canalbib>

- In Spain the initiative 'Nascuts per llegir' (Born to read) introduces library services to children ages 0 to 3 years by strengthening parent-child love of books and libraries. The initiative was developed by the Professional Catalan Association to promote reading amongst families. <http://nascutsperllegir.org>

\subsubsection{Working with the media}

Library staff should be trained to use communication media to promote the library service and respond to media enquiries. They should be able to write articles for local newspapers and prepare press releases. They should be familiar with the techniques of speaking and being interviewed on radio and television. They should also be able to promote the library and its services via computer and telecommunication networks including the creation of library websites and the development of library blogs, podcasts, RSS feeds and use of social media.

\subsubsection{Community support}

The library managers must ensure that the community is aware of the importance of the library service. Municipal, regional and national funding bodies should be made fully aware of the important place that the library occupies in the community, and support its development.

\subsubsection{Gaining community support}

The library should have an agreed policy and a sustained programme for developing community support. This can include: 
- maintaining a 'friends of the library' organisation for fund-raising and general support

- working with community advocates in support of major initiatives such as new buildings and services

- forming liaisons with community groups to enhance parts of the collection or strengthen specific services

- working with groups that wish to speak out on behalf of the library service and its development

- participation by library staff in activities aimed at increasing awareness of the variety and value of the library service.

The support of the community also depends on the library delivering the services it has promised to deliver.

\subsubsection{Advocacy}

The library should have established and adopted written policies that define its role in generating public support for the library service.

A well informed public can provide valuable support for the public library service and actively promote it within the community. Getting people to talk positively about the library and its services is one of the most effective marketing tools. Lobbying involves interaction with decision-makers to secure specific objectives at an appropriate point in the legislative, policy-making or budget process.

\subsubsection{Working with governing bodies}

Library managers should meet at least annually with the library's principal governing and funding body to review the library's services, development plans, achievements and obstacles. Librarians should look for as many opportunities as possible to involve its governing body in its major activities. Events such as the opening of a new library, the launching of a service, the installation of public Internet access, the opening of a new collection and the inauguration of a fund-raising drive can be used for this purpose.

\subsubsection{Participation in community life}

One of the most effective promotional strategies is the participation of well-informed library staff and committee or board members in community activities. Examples include: 
- presenting book and activity reviews on radio and television

- working with adult and children's literature and cultural groups

- writing a newspaper column

- supporting literacy organisations and campaigns

- participating in the activities of local organisations

- assisting with school-based initiatives

- participating in local history and genealogy societies

- being a member of a service organisation, e.g., Rotary International

- visiting local organisations to promote the library service.

\section{Resources}

12manage. (n.d.) 12 manage: The executive fast track.

(http://www.12manage.com/management_views.asp accessed 1/01/2010).

Dempsey, K. (2009). The accidental library marketer. Medford, NJ: Information Today.

Dowd, N; Evangeliste, M; and Silberman, J. (2009). Bite-sized marketing: realistic solutions for the overworked librarian. Chicago: ALA Editions.

Fisher, P. H., Pride, M. M., and Miller, E.G. (2006). Blueprint for your library marketing plan: A guide to help you survive and thrive. Chicago: American Library Association.

Flaten, T. (2006). Management, marketing and promotion of library services based on statistics, analyses and evaluation. Munich: K.G. Saur.

Gupta, D. (2006). Marketing library and information services: International perspectives. Munich: K.G. Suar.

Gupta, D. (n.d.). Marketing-mantra-for-librarians: Library marketing: Imperative to userfocused services in your library.

(http:/ / marketing-mantra-for-librarians.blogspot.com/ accessed 1/01/2010).

Kendrick, T. (2006). Developing strategic marketing plans that really work: A toolkit for public libraries. London: Facet.

Koontz, C.M. (2002-2009). Customer-based marketing columns. Medford, NJ: Information Today. Some issues are online (http://www.infotoday.com/MLS/default.shtml accessed 3/27/2010).

Koontz, C.M. (2001). Glossary of marketing definitions: IFL A Section on Management and Marketing. (http://archive.ifla.org/VII/s34/pubs/glossary.htm> accessed 3/9/ 2010.)

Kujawski, M. (2008). What would happen if the STOP sign was invented in 2008? Public Sector Marketing 2.0. (http://www.mikekujawski.ca/2008/12/17/what-wouldhappen-if-the-stop-sign-was-invented-in-2008/ accessed 1/01/2010). 
Lake, Laura. (2009). Understanding the Role of Social Media in Marketing. (http://marketing.about.com/od/strategytutorials/a/socialmediamktg.htm accessed 3/15/2009).

Online Computer Library Center, Inc. (OCLC). (2005). Perceptions of Libraries and Information Resources. (http://www.oclc.org/reports/2005perceptions.htm accessed $1 / 01 / 2010)$.

Savard, R. (2000). Adapting marketing to libraries in a changing and world-wide environment. Munich: K.G. Saur.

Wolfe, L. A. (2005). Library public relations, promotions, communications: $A$ bow to do it manual. New York: Neal Schuman Publishers.

Woodward, J. (2005). Creating the customer-driven library: Building on the bookstore model. Chicago: American Library Association.

Wymer. W. (2006). Nonprofit marketing: Marketing management for charitable and nongovernmental organizations. Thousand Oaks, CA.: Sage Publications, Inc. 
